\title{
The Influence of Services' Quality on Intention to Revisit through \\ Mediation of Satisfaction of Visitors at Sasak Sade Village, Central Lombok, West Nusa Tenggara
}

\author{
Rahman $^{1}$, I Gusti Ayu Oka Suryawardani ${ }^{2}$ and Agung Suryawan Wiranatha ${ }^{2}$ \\ ${ }^{1}$ Master Program in Tourism Udayana University \\ ${ }^{2}$ Centre of Excellence in Tourism Udayana University \\ Corresponding author : suryawardani@unud.ac.id
}

\section{ARTICLE INFO}

Received

5 August 2019

Accepted

18 September 2019

Available online

30 September 2019

\section{ABSTRACT}

The Sasak Sade Village is inhabited by a people from generation to generation. As a place that has been known and visited by many tourists, the management of the Sasak Sade Village offers traditional building house and daily activities of local people as tourist attractions. It is very important to have good quality services to increase revisit intention in the future. The purposes of this research were to determine service quality that influences tourist satisfactions and revisit intention in Sasak Sade Village. This study used 85 respondents of domestic tourists and a purposive sampling technique. The analysis used in this study was a structural equation modeling (SEM) by using Smart Partial Least Square (PLS) 3.0. This study tested two models namely outer model to predict the relationship between indicator and variable, and inner model to predict between two variables. The results of this research were: 1) the service quality significantly influenced the tourist satisfaction at the Sasak Sade Village; 2) the tourist satisfaction significantly influenced their revisit intention at the Sasak Sade Village; and 3) the service quality significantly influenced their revisit intention at the Sasak Sade Village.

Keywords: Service Quality, Tourist Satisfaction, Revisit Intention

\section{INTRODUCTION}

\section{Background}

The tourism attraction of Sasak Sade Village is an unspoiled place in which the order of people's lives is still simple or traditional. Local people in carrying out activities of daily life still uphold the traditions that originate from their ancestors such as the marriage system, social system, and government system. One of the main attractions in the Sasak Sade Village Tourism Destination Region is the building of houses occupied by local people as well as unique tourist attractions. Sasak Sade Village Tourism 
Destination has an area of about 30,000 $\mathrm{m}^{2}$, and is inhabited by 162 families or around 700 people. The livelihoods of local people are currently farming, raising cattle and buffalo, as local tour guides, weavers, and souvenir sellers.

An interesting thing that is unique to Sasak Sade Village is the tradition of cleaning the floor of the house using buffalo dung. According to public belief, cleaning the floor of a house with buffalo dung is to keep the floor clean. Another unique tradition that applies in the community is the marriage system within the family (consanguineous marriage) and is still in the Sasak Sade Village environment. The uniqueness mentioned above that causes many tourists to visit the Sasak Sade Village.

The problem experienced by tourists is unsatisfactory services. Tourists who are dissatisfied with the services usually complain to management through the local tour guides. Services that often cause tourists to feel disappointed include local tour guide services during the peak tourist season; they often do not do their job as well as possible, such as incomplete information, they often do not use loudspeakers for tourists who come in groups, and seeming to rush in delivering information. The problems that occur with souvenir sellers are that differences in prices with the same brand and quality of http://ojs.unud.ac.id/index.php/eot goods and goods sold are found elsewhere. The problem of tourist attractions that are not shown every day, causing tourists often disappointed and not in accordance with the information obtained before visiting. Public facilities such as limited toilets, inadequate parking areas when compared to the number of tourist vehicles,and environmental cleanliness at the Sasak Sade Village tourist destination is still not satisfactory.

This research is important so that the management of the Sasak Sade Village tourist destination understands the real needs of visitors, especially the quality of the services prepared. The management of the Sasak Sade Village tourist destination must also understand the expectations of tourists so that tourists intend to come back. This research will be used as a standard of service to tourists and then to be applied to people who are involved directly or indirectly in serving visitors such as local tour guides, local communities, and souvenir traders. The excellent and poor quality of services depends on the ability of service providers to meet customer expectations consistently. The perceived value of the customers is the difference between the prospective customers' valuation of all the benefits and costs of an offer on the alternative, Kotler and Keller (2009: 136). The ultimate goal of a business is to create 
satisfaction for its customers. In general, satisfaction is someone's feeling of pleasure or disappointment arising from comparing the perceived performance of the product with the expectations. Kotler and Keller (2009: 138-139). After the customer's expectations are met, the thing the business owner has been waiting for the most is the customer's desire to come back. According to Heiler in Margee (2008), repurchase intention is defined as individual assessments of repurchase services and the decision to engage in future activities with service providers and the forms taken. According to Zeithaml and Bitner (2006), the dimensions representing evaluative criteria of customers for assessing service quality consist of tangibility, reliability, responsiveness, assurance, and empathy.

This study wants to analyze how tourists 'assessment of the service dimensions available at the Sasak Sade Village tourist destination which is an indicator to find out what service quality is like, then it will be analyzed how it affects the direct satisfaction of tourists and tourists' revisit intentions.

\section{Research Objectives}

The objectives of this research are:

i) Analyzing the effect of service quality on the satisfaction of tourists visiting the Sasak Sade Village, Central Lombok, West Nusa Tenggara,

ii) Analyzing the effect of satisfaction on tourist revisit intention at the Sasak Sade Village, Central Lombok, West Nusa Tenggara,

iii)Anlyzing the effect of service quality on tourist revisit intentions at the Sasak Sade Village, Central Lombok, West Nusa Tenggara.

\section{LITERATURE REVIEW}

\section{Definition of Quality of Service}

Zeithaml and Bitner (2006: 116-119; Suryawardani, et. al., 2017: Suryawardani, et. al., 2018 and Yoga, et al., 2016) put forward the dimensions of service quality into five (5) as follows:

1. Tangibility is the ability to demonstrate its existence to external parties, this includes physical facilities and infrastructure.

2. Reliability is the ability to provide services in accordance with what has been previously promised accurately and reliably. Performance rating should be in line with expectations as punctuality, reducing errors, and sympathetic attitude. 
3. Responsiveness is a willingness to help and provide fast and appropriate services to tourists with clear information.

4. Guarantee and assurance includes knowledge, courtesy, and the ability to foster trust in the services being sold. This includes communication, credibility, security, manners.

5. Empathy is giving sincere individual attention to tourists by understanding tourists' desires.

\section{Tourist Satisfaction}

Oliver in Supranto (2006) argues that satisfaction is the level of one's feelings after comparing the performance or results felt with expectations, According to Kotler (2005) satisfaction is the number of attributes of a product or service. According to Engel in Tjiptono (2004) that customer satisfaction is a postpurchase evaluation in which the alternative chosen at least gives the same or higher than expected results. Dissatisfaction occurs when the results are lower than expectations (Suryawardani, et. al., 2017, Suryawardani, et. al., 2018 and Yoga, et al., 2016).

\section{Revisit Intention}

Before discussing revisit intention, it is necessary to first understand the http://ojs.unud.ac.id/index.php/eot definition of purchase intention. According to Mowen (2002: 55) purchase intention is a determinant of the buyer to take an action such as buying a product or service. According to Fullerton, Taylor in Jasfar (2002) that repurchase intentions are as purchase intentions, namely a strong desire to repurchase. Revisit intention as the customer's desire to make repeated visitation in the future (Suryawardani, et. al., 2017, Suryawardani, et. al., 2018 and Yoga, et al., 2016).

\section{RESEARCH METHOD}

\section{Research Location and Time}

This research was conducted in the Tourism Attraction of Sasak Sade Village (traditional house), Rembitan Village, Central Lombok Regency, West Nusa Tenggara. The study was conducted from December 2018 to February 2019, the implementation lasted for three months starting from data collection, questionnaire distribution, data processing, data analysis, and concluding it.

\section{Determination of Research Samples}

According to Sugiyono, (2008: 116), the sample is a portion of the number and characteristics possessed by the population. In this study the sample is 
the archipelago tourists visiting the Sasak Sade Village tourist destination, the intended tourists are those who come directly to the tourist destination using the Travel Agency or Travel Agent. The sample size recommended by Partial Least Square (PLS) ranges from 30 to 100 samples, Gozali (2011). Determining the sample size in general can be done by the number of indicators multiplied by 5 or 10, according to Hair et.al. (2010) the number of samples is at least 5 times the number of indicators. There are 17 indicators in this study and to get a representative number of samples the total indicator number is multiplied by the minimum number of samples (5 times) and the result is the sample size $(17 \times 5=$ $85)$. So the number of samples determined in this study was 85 respondents. The reason for determining the sample size by the total indicator multiplied by 5 is to gain the ideal number between 30 to 100 respondents and maximum analysis results.

Based on these criteria to get the maximum analysis results the questionnaire is distributed by means of purposive sampling that is determining the sample with certain considerations. According to Sugiyono (2015) Purposive Sampling is a sampling technique with certain considerations. Tourists with certain considerations are tourists who http://ojs.unud.ac.id/index.php/eot come to the Sasak Sade Village tourist destination using the services of a Travel Bureau (BPW) or Travel Agent.

\section{Data Collection}

There are several stages in the data collection process as follows:

1. Observation is a technique of visiting a place that is used as the object of research in this case the Sasak Sade Village tourist destination, the aim is to directly observe the activities of the community and tourists, the environment, attractions, and a general description of the research location.

2. Questionnaire distribution is data collection by distributing questionnaires to tourists who have finished visiting the Sasak Sade Village tourist destination. The aim is to find out how tourists think about tourist destinations, management, society, environment, tourists in the Sasak Sade Village tourist destination. Data obtained from the results of the questionnaire will be processed into ordinal data, and the level of assessment uses a Likert scale: a scale of 5 (1; dissatisfied, 2: less satisfied, 3: quite satisfied, 4: satisfied, 5: very satisfied). 
3. Interview technique is to do data collection by question and answer with the management of tourist destinations and related people. This technique is carried out to clarify the purpose of the items being assessed in a questionnaire and to find out more about the services available at the Sasak Sade Village tourist destination.

4. Documentation study is a data collection technique in the form of destination monograph documents, community activities, and service activities for tourists in the Sasak Sade Village tourist destination, and then documentation data is used as evidence to complement the things that are lacking in this study.

\section{Variables and Indicators}

This research generally has two variables as follows:

1. Exogenous latent variables are variables that affect other latent variables. In this research, exogenous variables are taken based on the theory of Parasuraman (1990) in Tjiptono (2005) which classifies service quality into five dimensions: tangible, reliability, responsiveness, assurance, and http://ojs.unud.ac.id/index.php/eot empathy. Research variables and indicators are determined based on theory and adjusted to the conditions of the research location in the Sasak Sade Village tourist destination. The exogenous variable in this study is the quality of service marked with (X).

2. Endogenous latent variables are variables that are influenced by other latent variables. In this study endogenous latent variables are tourist satisfaction and revisit intention. There are two types of endogenous latent variables in this study as follows:

a. The revisit intention variable is given a sign or symbol (Y1).

b. Endogenous latent variables are intervining variables which also influence when exogenous variables affect endogenous variables. In this research endogenous intervening variables are tourist satisfaction given a sign or symbol (Y2).

\section{Data analysis method}

The method used to analyze this research data is the Smart PLS version 3.0 program. Outputs were analyzed using 
quantitative and qualitative descriptive approaches. Some stages in analyzing data consist of (three) stages as follows:

1. Outer model test (measurement model test) which is a model for analyzing the ability of indicators to reflect variables.

2. Inner model test (structural model test) which is a test to analyze the effect of one variable with another variable.

3. Model fit test (model feasibility test) which is a test to analyze the appropriateness of the designed model.

\section{Characteristics of Respondents}

Characteristics of respondents in this study were classified into several criteria including: Character of tourists based on sex divided into two: male and female. The character of tourists based on age is divided into five criteria namely $<20$ years, 21-30 years, 31-40 years, 4150 years, and $>50$. The character of tourists based on the region of origin in the group based on the origin of the province, the character of tourists based on occupation is divided into five criteria, namely students, company employees, entrepreneurs, retirees, and others. The

character of tourists based on the purpose of the visit is divided into three: vacation, business, other. The character of tourists is based on the frequency of visits to Lombok, and the frequency of visits to the Sasak Sade Village tourist destination.

\section{Convergent Validity Test}

The results of the analysis show that the loading factor has fulfilled the requirements $>0.7$ as can be seen in Table 1.

Table 1. The Loading Factor Value for each Indicator

\begin{tabular}{llll}
\hline Indicator & $\mathrm{X}$ & $\mathrm{Y} 1$ & $\mathrm{Y} 2$ \\
\hline LYN3 & 0.837 & & \\
LYN4 & 0.823 & & \\
LYN5 & 0.754 & & \\
LYN6 & 0.820 & & \\
LYN7 & 0.884 & & \\
\hline KEP1 & & 0.846 & \\
KEP3 & & 0.726 & \\
KEP4 & & 0.762 & \\
KEP5 & & 0.771 & \\
\hline NKU1 & & & 0.837 \\
NKU3 & & & 0.870 \\
\hline
\end{tabular}

The latent variable is different from the other latent variables, by looking at the cross loading value> 0.7 and the Average Variance Extracted (AVE) value of each latent variable has a value> 0.5 Gozali (2014). The results of the research validity test can be seen in Table 2 . 
Table 2. Results of Discriminant Validity Analysis

\begin{tabular}{lclcl}
\hline \multirow{2}{*}{ Variables } & \multirow{2}{*}{ AVE } & \multicolumn{3}{l}{ Cross Loading } \\
\cline { 3 - 5 } & & $\mathrm{X}$ & Y1 & Y2 \\
\hline $\begin{array}{l}\text { Revisit } \\
\text { intention }\end{array}$ & 0.728 & 0.853 & & \\
Satisfaction & 0.604 & 0.741 & 0.777 & \\
$\begin{array}{l}\text { Quality of } \\
\text { Service }\end{array}$ & 0.680 & 0.717 & 0.757 & 0.825 \\
\hline
\end{tabular}

Source: Respondent Data Analysis, 2019

Based on Table 2, it can be seen that each variable has a cross loading value> 0, 70 and an Average Variance Extracted (AVE) value> 0.5. This shows that all variables used in this study were classified as good or valid.

\section{Reliability of Construct (Composite Reliability) and Cronbach Alpha}

Construct reliability can be measured by the first two criteria with composite reliability, the second with Cronbach alpha from indicators that reflect the construct (Latent Variable). The construct can be categorized as reliable if the composite reliability value and Cronbach alpha> 0.70. The results of the construct reliability test can be seen in Table 3.
Table 3. Results of Constructi Reliability Test Analysis

\begin{tabular}{lll}
\hline Latent Variables & $\begin{array}{l}\text { Cronbach } \\
\text { Alpha }\end{array}$ & $\begin{array}{l}\text { Composite } \\
\text { Reliability }\end{array}$ \\
\hline Quality of Service & 0.883 & 0.914 \\
Satisfaction & 0.781 & 0.859 \\
Revisit intention & 0.712 & 0.843 \\
\hline
\end{tabular}

Table 3 shows that the Cronbach alpha value> 0.7 and composite reliability value $>0.7$. The results of the analysis can be concluded that all constructs of latent variables are good and reliable.

\section{Output of Structural Equation Model of the Research}

Based on the model framework and hypotheses built in this study, the results of the analysis output model can be seen in Figure 1.

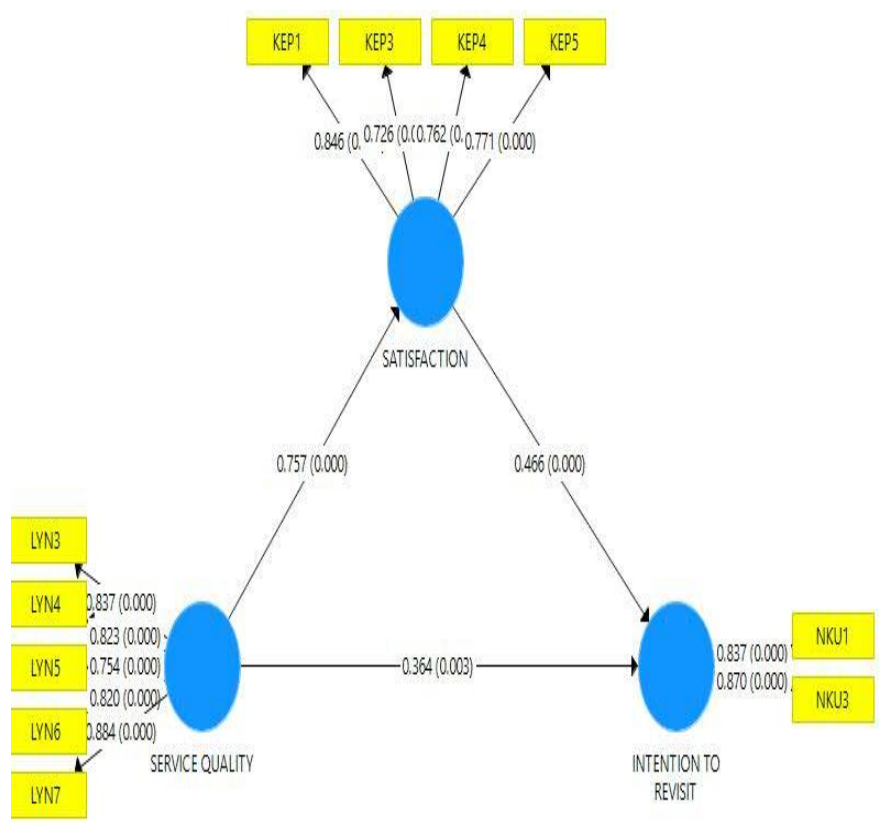

Figure 1. Output of Structural Equation Model of the Research 


\section{Measurement Model Analysis (Outer Model)}

Analysis of the measurement model shows the role of the indicators in reflecting the variables formed or showing the relationship between the variables with their constituent indicators, Suryawardani (2018). In this study, the bootstrapping process was carried out twice with 500 iterations. The output of the analysis results of each latent variable are as follows:

\section{Measurement Model Analysis (Outer Model) on Latent Variable of Quality of Service}

The output of the measurement model analysis, which is also called the outer model analysis, shows the ability of indicators to reflect variables. The results of the measurement model output on service quality variables can be seen in Table 4.

Table 4. Results of Measurement Model Analysis on Service Quality Variables

\begin{tabular}{|c|c|c|c|c|c|}
\hline Code & Statement & $\begin{array}{l}\text { Outer } \\
\text { load- } \\
\text { ing }\end{array}$ & $\begin{array}{l}\text { Stan- } \\
\text { dard } \\
\text { of } \\
\text { error }\end{array}$ & $\begin{array}{l}\text { T- } \\
\text { Statis } \\
\text { tics }\end{array}$ & $\begin{array}{l}\text { Signi } \\
\text { ficance }\end{array}$ \\
\hline LYN3 & $\begin{array}{l}\text { Ability to } \\
\text { provide } \\
\text { services }\end{array}$ & $\begin{array}{l}0,83 \\
7\end{array}$ & 0,028 & 29,398 & $\begin{array}{l}\text { Signi } \\
\text { ficant }\end{array}$ \\
\hline LYN4 & $\begin{array}{l}\text { Response } \\
\text { in } \\
\text { providing } \\
\text { services }\end{array}$ & $\begin{array}{l}0,82 \\
3\end{array}$ & 0,040 & 20,601 & $\begin{array}{l}\text { Signi } \\
\text { ficant }\end{array}$ \\
\hline LYN5 & $\begin{array}{l}\text { security } \\
\text { assurance } \\
\text { to tourists }\end{array}$ & $\begin{array}{l}0,75 \\
4\end{array}$ & 0,061 & 12,446 & $\begin{array}{l}\text { Signi } \\
\text { ficant }\end{array}$ \\
\hline
\end{tabular}

$\begin{array}{llllll}\text { LYN6 } & \begin{array}{l}\text { Manners/c } \\ \text { ourtesy }\end{array} & 0,82 & 0,058 & 14,256 & \begin{array}{l}\text { Signi } \\ \text { ficant }\end{array} \\ \text { LYN7 } & \begin{array}{l}\text { Ease of } \\ \text { communic } \\ \text { ation }\end{array} & 0,88 & 0,029 & 30,292 & \begin{array}{l}\text { Signi } \\ \text { ficant }\end{array} \\ & 4 & & & \end{array}$

The results of this study indicate that all indicators reflect significant service quality variables. Based on Table 4 , it can be seen that the LYN7 indicator (ease of communication) has the highest outer loading value (0.884), meaning that the communication ability of the local community is very good for visitors. Then followed by LYN3 indicator (ability to provide services) with loading factor (0.837), LYN4 indicator (response in providing services) with loading factor (0.823), LYN6 indicator (manners/courtesy) with loading factor (0.820) and, LYN5 indicator ( security assurance to tourists) with a loading factor (0.754). In this study, the indicator of security assurance to tourists has the smallest loading factor of 0.754 , meaning that the safety factor is still a concern of visitors because it is felt that it has not maximally satisfied visitors. Because there needs to be an improvement in the visitor's security system, especially when traveling around Sasak Sade Village. 
2. Analysis of Measurement Model (Outer Model) on Latent Variable of Satisfaction

Results of Measurement Model (Outer Model) on satisfaction variables can be seen in Table 5.

Table 5. Results of Analysis of Measurement Models on Satisfaction Variables

\begin{tabular}{llllll}
\hline Code & Statement & $\begin{array}{l}\text { Outer } \\
\text { Load- } \\
\text { ing }\end{array}$ & $\begin{array}{l}\text { Stan- } \\
\text { dard } \\
\text { of } \\
\text { Devi- } \\
\text { ation }\end{array}$ & $\begin{array}{l}\text { T- } \\
\text { Statis } \\
\text { tics }\end{array}$ & $\begin{array}{l}\text { Signi } \\
\text { ficance }\end{array}$ \\
\hline KEP1 & $\begin{array}{l}\text { Feel } \\
\text { happy } \\
\text { during a } \\
\text { visit }\end{array}$ & 0.846 & 0.044 & 19.217 & $\begin{array}{l}\text { Signi } \\
\text { ficant }\end{array}$ \\
KEP3 & $\begin{array}{l}\text { DSS is the } \\
\text { right } \\
\text { choice }\end{array}$ & 0.726 & 0.050 & 14.615 & Signi \\
KEP4 & $\begin{array}{l}\text { Enjoyable } \\
\text { experienc } \\
\text { e when } \\
\text { visiting }\end{array}$ & 0.762 & 0.079 & 9.704 & Signi \\
KEP5 & $\begin{array}{l}\text { Overall } \\
\text { satisfied } \\
\text { with the } \\
\text { service }\end{array}$ & 0.771 & 0.062 & 12.527 & Signi \\
ficant
\end{tabular}

Source: Processed Primary Data, 2019

The results of this study indicate that all indicators can significantly reflect satisfaction variables. Based on Table 5 it can be seen that the KEP1 indicator (Feeling happy when visiting) has the highest outer loading value (0.846), meaning that tourists when they visit get what was expected before. This is followed by KEP5 indicator (Overall satisfied with the services) with loading http://ojs.unud.ac.id/index.php/eot factor (0.771), KEP4 indicator (pleasant experience visiting with loading factor (0.762) and, in this study KEP3 indicator (tourist destination of Sasak Sade Village is the right choice) has the smallest loading factor of 0.726 . The results show that tourist satisfaction in choosing Sasak Sade Village as a visiting choice is appropriate even though this indicator has the smallest loading factor value among other indicators, because there needs to be an improvement in terms of promotion to match the true conditions in the field.

3. Analysis Results of the Measurement Model (Outer Model) on the Latent Variable of Revisit Intention

The results of the measurement model output (Measurement Model / Outer Model) on the variable intention intention can be seen in Table 6 . 
Table 6. Results of Analysis of Measurement Models on Variable of revisit intention

\begin{tabular}{llllll}
\hline Code & Statement & $\begin{array}{l}\text { Outer } \\
\text { Load- } \\
\text { ing }\end{array}$ & $\begin{array}{l}\text { Stan- } \\
\text { dard } \\
\text { of } \\
\text { Devi- } \\
\text { ation }\end{array}$ & $\begin{array}{l}\text { Statis } \\
\text { tics }\end{array}$ & $\begin{array}{l}\text { Signi } \\
\text { ficance }\end{array}$ \\
\hline NKU1 & $\begin{array}{l}\text { Desire to } \\
\text { be offered } \\
\text { other } \\
\text { attractions }\end{array}$ & 0.837 & 0.062 & 13.4 & $\begin{array}{l}\text { Signi } \\
\text { ficant }\end{array}$ \\
NKU3 & & & 61 & & \\
& $\begin{array}{l}\text { The desire } \\
\text { to } \\
\text { recommend } \\
\text { to others }\end{array}$ & 0.870 & 0.025 & 34.6 & $\begin{array}{l}\text { Signi } \\
\text { ficant }\end{array}$ \\
& & & 88 & & \\
\end{tabular}

The results showed that all indicators significantly reflected the variable of intention to revisit. Based on Table 4.6, it can be seen that the NKU3 indicator (the desire to recommend to others) has the highest loading factor value (0.870), meaning that the experience of tourists visiting the Sasak Sade Village tourist destination wants to be shared with relatives and others. Followed by the NKU1 indicator (desires offered with other attractions) with a loading factor value $(0.837)$. The results showed that variations in attractions needed to be increased to increase visitor activity and length of stay. Diverse tourist attractions and traditionally packaged according to local culture are expected to increase the intention of tourists visiting the tourist attraction of Sasak Sade.

\section{Structural Model Analysis Results (Inner Model)}

Analysis of the inner model shows the relationship between one variable with another variable. The path coefficient values of the relationships between variables in the structural equation model show the effect of one variable with another variable. There are several forms of influence that can be seen in the structural equation model (SEM), namely: direct effects, indirect effects, and total effects. The following describes each of these effects:

\section{Direct Effect of Exogenous Variables on Endogenous Variables}

The direct effects between one variable with other variables in this study is:

a. The effect of service quality on satisfaction indicates a moderate structural model with a value of $\mathrm{R}^{2}$ (0.573).

b. The effect of satisfaction on the intention to revisit indicates a moderate structural model with a value of $R^{2}$ (0.606).

c. The effect of service quality on the intention to revisit indicates a moderate structural model with a value of $R^{2}$ (0.606). 
Direct and indirect effects between exogenous variables and endogenous variables can be seen in Table 7. significant effect on revisit intention (Y2).

Table 7. Direct and Indirect Effects of Exogenous Variables to Endogenous Variables

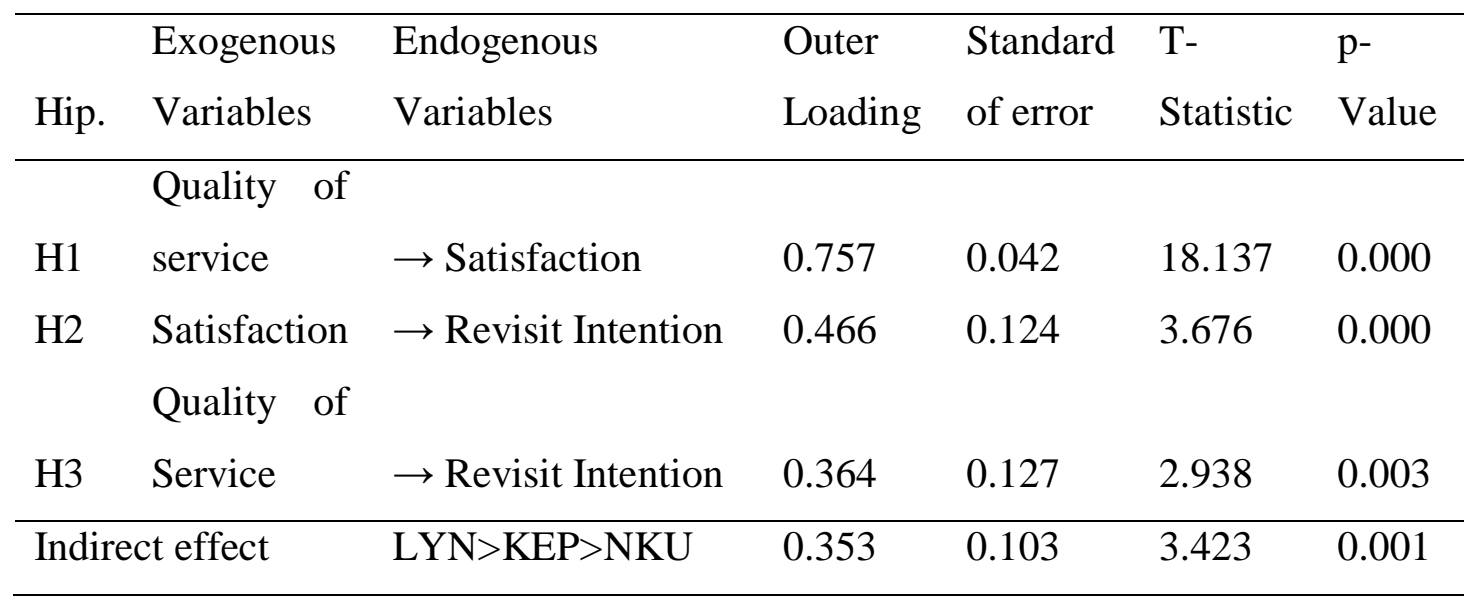

Based on Table 7, it can be seen that there are three direct effects supported significantly by the results of the analysis of the measured structural models. The results of the analysis of the direct effect of exogenous variables on endogenous variables are accepted if (t-statistic)> 1.96 and significance level $<0.05$ (5\%) Gozali (2014). The results of the analysis of the direct effect of each variable in this study obtained three (3) hypotheses as follows:

a. The value of effect between constructs shows that service quality (X) has positive and significant effect on tourist satisfaction (Y1).

b. The value of the effect between constructs shows that tourist satisfaction (Y1) has a positive and c. The value of the effect between constructs shows that service quality (X) has a positive and significant effect on revisit intention (Y2).

\section{The indirect effect of exogenous variables on endogenous variables}

Based on Table 7, it was obtained the value of the effect of service quality (X) on tourist revisit intention (Y2) by mediating tourist satisfaction (Y1) with a coefficient value (0.353) and significance level of $<0.05(5 \%)$. It can be concluded that the latent variable of satisfaction can mediate the effect of service quality on tourist revisit intention to the Sasak Sade Village tourist destination. 


\section{Total Effect of Exogenous Latent on Endogenous Latent}

The combination of direct and indirect effects forms the total effect of an exogenous latent variable on an endogenous latent variable with a significance level of $<0.05$. The effect of total exogenous latent on endogenous latent can be seen in Table 8 .

Table 8. Total Effects of Exogenous Latent on Endogenous Latent

\begin{tabular}{|c|c|c|c|c|c|}
\hline $\begin{array}{l}\text { Exo } \\
\text { genous } \\
\text { Variables }\end{array}$ & $\begin{array}{l}\text { Endo } \\
\text { genous } \\
\text { Variables }\end{array}$ & $\begin{array}{l}\text { Outer } \\
\text { Load- } \\
\text { ing }\end{array}$ & $\begin{array}{l}\text { Stan- } \\
\text { dard } \\
\text { of } \\
\text { error }\end{array}$ & $\begin{array}{l}\text { T- } \\
\text { Statis } \\
\text { tic }\end{array}$ & $\begin{array}{l}\mathrm{p}_{-} \\
\text {value }\end{array}$ \\
\hline$\overline{\mathrm{LYN}}$ & --> KEP & 0.757 & 0.042 & 18.137 & 0.000 \\
\hline KEP & $-->$ NKU & 0.466 & 0.127 & 3.676 & 0.000 \\
\hline YN & $->\mathrm{NKU}$ & 0.717 & 0.061 & 11.682 & 0.000 \\
\hline
\end{tabular}

Table 8 shows the results of an analysis of the effect of total exogenous latent on endogenous, as follows:

a. Total service quality has a positive and significant effect on tourist satisfaction with a p-value of $0,000<0.05$.

b. Total tourist satisfaction has a positive and significant effect on tourist revisit intention with a p-value of $0,000<0.05$.

c. Total service quality has a positive and significant effect on tourist revisit intention with a p-value of $0,000<0.05$.

\section{Results of Feasibility Model}

Prior to the interpretation of the results of the structural equation model analysis in this study, several previous studies such as Fornel \& Larcker, (198); Chin et al. (2003); Hair et al. (2012); Henseler et al. (2009), Suryawardani, (2018) recommend the feasibility of the model for checking. Common measures are used to assess the feasibility of structural equation models that are analyzed with SEM models based on Smart PLS 3.0 as can be seen in Table 9.

Table 9. Statistical Values for Assessing the Feasibility of Variables

\begin{tabular}{lllll}
\hline Variables & $\begin{array}{l}\text { Variable } \\
\text { type }\end{array}$ & $\begin{array}{l}\text { Number } \\
\text { of } \\
\text { indica- } \\
\text { tors }\end{array}$ & AVE & $\mathrm{R}^{2}$ \\
\hline $\begin{array}{l}\text { Quality of } \\
\text { Service }\end{array}$ & Exogen & 5 & 0.680 & $\mathrm{NA}^{\mathrm{a}}$ \\
\hline $\begin{array}{l}\text { Satisfaction } \\
\text { Endogenous }\end{array}$ & $\begin{array}{l}\text { Endening } \\
\text { Intervening }\end{array}$ & 0.604 & 0.573 \\
$\begin{array}{l}\text { Revisit } \\
\text { intention }\end{array}$ & Endogen & 2 & 0.728 & 0.606 \\
\hline $\begin{array}{l}\text { Nilai Rata- } \\
\text { rata }\end{array}$ & & & $0.641^{\mathrm{b}}$ & $0.589^{\mathrm{b}}$ \\
\hline
\end{tabular}

According to Chin (2003), in Suryawardani (2018), endogenous latent variables with $\mathrm{R}^{2}$ values range from 1.19 to 0.33 , indicating that the structural model is weak, if it is in the range of 0.33 to 0.67 , the structural model is moderate and , if it is above 0.67 it is indicated that the structural model is strong. In this study, the feasibility test of the model is 
done by looking at the value of $\mathrm{R}^{2}$ as follows:

a. $\mathrm{R}^{2}$ value of visitor satisfaction variable $\mathrm{Y} 1$ is 0.573 , the structural model shows latent visitor satisfaction has predictive power with moderate category. It can be concluded that the model of $57.3 \%$ variants of latent variables of visitor satisfaction can be explained by all latent variables, namely dimensions of service quality.

b. $\mathrm{R}^{2}$ value of revisit intention $\mathrm{Y} 2$ variable is 0.606 , structural model shows latent visitor satisfaction has predictive power with moderate category. It can be concluded that the model of $60.6 \%$ variant of the latent variable revisit intention can be explained by all latent variables of tourist satisfaction.

The feasibility test of the Goodness of Fit model (GoF) can be measured based on the value of the Standardized Root Mean Residual (SRMR) and Normed Fit Index (NFI). GoF is said to be fit if the SRMR value $<0.10$ and the NFI value $<0.9$. The results of the Goodness of Fit structural equation model can be seen in Table 10 .
Table 10. Goodness of Fit model test results

\begin{tabular}{lll}
\hline & Saturated Model & Estimated Model \\
\hline SRMR & 0.084 & 0.084 \\
NFI & 0.767 & 0.767 \\
\hline
\end{tabular}

Based on Table 4.10, it can be seen that the value of Standardized Root Mean Residual (SRMR) is 0.084 and the Normed Fit Index (NFI) value is 0.767 so that the research model is feasible.

\section{DISCUSSION}

The results of this study indicate that there is an influence of service quality on tourist satisfaction in the Sasak Sade Village tourist destination. The results of this study are in accordance with the theory put forward by Zeithmal and Bitner (2003) that satisfaction is also influenced by service quality, ie consumers feel satisfied if they get good service or as expected. Based on some of these theories strengthen the belief that tourist satisfaction is strongly influenced by the quality of services offered at the Sasak Sade Village tourist destination.

The results of this study support some of the results of previous studies such as Chien (2010) who concluded that service quality can affect satisfaction. Akama (2003) also mentioned that more than $70 \%$ of tourists were satisfied with 
the quality of service in a tourist destination. Yuda (2018) concluded that service quality has a positive and significant effect on tourist satisfaction.

The results of the analysis use Structural Equation Modeling (SEM) that service quality indicators have different perception values on the service quality variables. Overall, tourists' perceptions of service quality are on average satisfactory with a value of 3,999. Referring to Table 4.4 , it can be seen that the Indicator of ease of communication with tourists has the highest reflexive value of 0.884 on the service quality variable in the Sasak Sade Village tourist destination. It can be said that the quality of public communication directly involved in serving visitors has a good level of communication. Meanwhile, indicator of ability to provide good services also has a high perception value. Indicator of manners or courtesy of the local community in serving visitors is also perceived very well. While, the indicator of the response of the local community in providing services at the Sasak Sade Village tourist destination is well perceived and lastly, indicator of security and safety guarantees to tourists have the lowest perception of 0.754 among all indicators, even though it is still in a significant level.

Guaranteed tourist safety and security is one of the responsibilities of http://ojs.unud.ac.id/index.php/eot the management of the Sasak Sade Village tourist destination. Tourist perceptions related to the security and safety are low, although still in a significant level. Some reasons for the perception of security and safety of tourists have a low reflexive value are: i) there is no guarantee of safety and safety of tourists in writing, ii) there is no smoking ban, even though the roof of the building uses flammable thatched roof, iii) there is no CCTV to monitor the safety of visitors, iv) the sanitary or cleanliness conditions of the Sasak Sade Village tourist destination are still not optimal, there are still many household wastes that are not taken care of.

The results of the study of satisfaction affect the revisit intention to the Sasak Sade Village tourist destination with a coefficient value of 0.466 . This means that tourist satisfaction can affect revisit intention by $46.6 \%$ in the Sasak Sade Village tourist destination, while the other $53.4 \%$ revisit intention is influenced by other factors. Therefore, greater tourist revisit intention is influenced by other factors beyond satisfaction, it can be interpreted that tourist satisfaction can affect a small portion of tourists revisit intention to Sasak Sade Village tourist destination.

The results of this study support the results of previous studies such as Elisa (2007) who reported that there is an 
influence of service quality and satisfaction on behavioral intentions in the tourism industry. According to Suryawardani (2016) that consumer satisfaction has a positive relationship with loyalty. Affirmed by Suryawardani (2018) that the intention to visit is significantly affected by attitude towards behavior and perceived behavioral control. This means that the more happy tourists are when they visit and the more attractions tourists enjoy at attractions, the more likely they are to revisit in the future. According to Wiranatha (2015) that overall the level of customer satisfaction has not been reached because of performance.

Descriptive analysis results show that the satisfaction factor is one of the perceived by respondents for the assessment of tourist revisit intention in the Sasak Sade Village tourist destination. The results of the analysis using Structural Equation Modeling (SEM) show that the indicators forming visitor satisfaction have different perception values on the satisfaction variable. Overall, tourists' perceptions of satisfaction in the Sasak Sade Village tourist destination averaged 3.972. Referring to Table 4.5 , it can be seen that the indicator feels happy when visiting has the highest reflexive value of 0.846 on the visitor satisfaction variable. Indicators of visitors are satisfied with the http://ojs.unud.ac.id/index.php/eot services available at the Sasak Sade Village tourist destination and indicator of pleasant experiences while visiting the destination also affect visitor satisfaction, as well as the indicator of Sasak Sade Village tourist destination is the right choice have the smallest reflexive value of 0.726 but still in a significant level.

The perception of tourists about the Sasak Sade Village tourist destination has not been the right choice to visit. Seeing the reality in the field the reasons that the Sasak Sade Village tourist destination has not become an appropriate tourist destination are: i) limited tourist attractions available, ii) to get local cultural performance services must go through the booking process before tourists visit, iii) short tourist visiting times because lack of available tourist attractions, iv) there are similar tourist attractions in close proximity.

Revisit intention of tourists appear when during their visit they get many satisfying pleasures, many attractions are enjoyed and followed by tourists during the visit. Getting a good and satisfying experience is also very influential on tourist satisfaction so there will be an intention to re-visit to look for new experiences in the future to these attractions. Tourists who come want their expectations fulfilled, then the desire to come again will not consider everything 
that makes disappointed. It can also be said that returning tourists positively support the relationship between tourist satisfaction with the intention of returning to the Sasak Sade Village in the future. Customer satisfaction can provide several benefits, such as the relationship between the management of the tourist destination Sasak Sade Village and tourists who visit to be good, provide a good basis for revisit intention and the creation of a good story about the condition of the tourist destination, and form a word of mouth recommendation which is beneficial for the Sasak Sade Village tourist destination. The results of this study indicate that service quality influences visitor satisfaction at the Sasak Sade Village tourist destination with a coefficient value of 0.364 . This means that service quality can affect revisit intention by $36.4 \%$ Sasak Sade Village tourist destination, while the other $63.6 \%$ revisit intention is influenced by other factors. Because revisit intention is influenced more by other factors than service quality, it can be interpreted that in this study only a small portion of tourist revisit intention can be influenced by service quality at Sasak Sade Village tourist destination.

The results of this study are in accordance with the opinion of Tjiptono (2008) that there are several factors that make tourists have the intention to come http://ojs.unud.ac.id/index.php/eot back, namely facilities and products. The results of this study also support the research of Yuda (2018) that service quality has a positive and significant effect on loyalty. Reinforced by Suryawardani (2017) that intrinsic and extrinsic motivation significantly influence the loyalty of foreign tourists visiting nature tourism with media satisfaction.

In the results of descriptive analysis, the service quality factor is one of the perceived by respondents for the assessment of tourist revisit intention in the Sasak Sade Village tourist destination. The results of the analysis using Structural Equation Modeling (SEM), the indicators forming the quality of service have different perceptual values of the intention to revisit variables. Overall tourist perceptions of revisit intention on average agree with the value of 4.087 . Referring to Table 4.6, it can be seen that the perception of the Indicator of the desire to add tourist attractions in the Sasak Sade Village tourist destination is high by 0.837 . The addition of tourist attractions can give a new impression for tourists, so there is an intention to revisit in the future. Based on the facts in the field that it is necessary to add tourist attractions to increase the intention of tourists visiting again, besides that it can also prolong the time of visiting the Sasak Sade Village e-ISSN: 2407-392X. p-ISSN: 2541-0857 
tourist destination. Quality of service has little influence on the revisit intention of tourists in the tourist destination of Sasak Sade Village. The revisit intention is more influenced by other factors. Based on the reality in the field, other factors that are suspected to influence the revisit intention are facilities and products. From this fact it is very important to sell quality products and add public facilities according to the needs of tourists.

\section{CONCLUSION}

Based on the results of the discussion of this study, some conclusions can be drawn as follows:

1. Quality of service has a positive and significant effect on tourist satisfaction at the Sasak Sade Village tourist destination. Each of the indicators forming latent variables of service quality also has a strong and significant reflexive average. The relationship between service quality and tourist satisfaction at the Sasak Sade Village tourist destination has a strong connection. This means that overall service quality indicators can satisfy tourists in the Sasak Sade Village tourist destination, although there are less than optimal indicators such as security and safety guarantees have the smallest reflexive but still at a significant level.
2. Tourist satisfaction has a positive and significant influence on revisit intention to the Sasak Sade Village tourist destination. Each of the indicators forming latent variables of satisfaction also has a strong and significant reflexive average. The relationship between satisfaction variables with tourist revisit intention in the Sasak Sade Village tourist destination has a less strong connection. Tourist revisit intention is largely influenced by factors beyond satisfaction. This means that overall satisfaction can directly influence the revisit intention of tourists in the Sasak Sade Village tourist destination with a less strong influence value.

3. Quality of service has a positive and significant effect on tourist revisit intentions in the Sasak Sade Village tourist destination. Each of the indicators forming latent variables of service quality also has a strong and significant reflexive average. The relationship between service quality variables with tourist revisit intention in the Sasak Sade Village tourist destination has little effect. Revisit intention of tourists is largely influenced by factors outside the quality of service.

e-ISSN: 2407-392X. p-ISSN: 2541-0857 


\section{REFERENCES}

Assael, H. 1998. Consumer Behavior and Marketing Action $6^{\text {th }}$ Edition. New York: South Western Collaege.

Chien M. C., T.L. H.C. Hong, H.C Sheu, H.H. Tsun. 2010. Tourist Behavioural intentions in relation to service quality and customer satisfaction in kinmen National park,Taiwan. International Journal of tourism Research. 13,416432.wileyonline liberary.com

Chin, W.W. 2003. A Partial Least Square Laten Variable Modeling Approach for Measuring Ineraction effect Information System Research. 14(2), pp.189-217

Eka N. K., S.W. Agung, I. G. A. O Suryawardani., 2018. Statistik Pariwisata Sebuah Review Ringkas. Konsorsium Riset Pariwisata. Universitas Udayana.

Fornell, C. \& Lacker, D. F. 1981. Evaluating Struktural Equation Models with Unobserable Variabel and Measurement Error. Journal of Reaserch, 18(1)39-50.

Gozali . 2011. Aplikasi Analisis Multivariat dengan program IBM SPSS 19. Edisi 5) Semarang. Universitas Diponogoro.

Gozali. 2014. Konsep dan Aplikasi dengan program AMOS 22.0. semarang. Badan penerbit: Universitas Diponogoro.

Gozali. 2006. Aplikasi analisis multivariate dengan SPSS. Semarang. Badan penerbit: Universitas Diponogoro.

Gozali. 2014. Structural Equation Modeling Metode alternative dengan Partial Least Square (PLS) 3.0.Semarang. Universitas Diponogoro.
Hair, J. F., W.C. Black, B.J. Babin,dan R.E. Anderson. 2010, Multivariat Data Analysis $7^{\text {th }}$ Edition. Pearson Prentice Hall

Jasfar, F. 2002. Kualitas Jasa dan Hubungannya dengan Loyalitas serta Komitmen Konsumen: Studi pada Pelanggan Salon Kecantikan. Jurnal siasat Bisnis.Vol.17.no.1.4346.

John, S. Akama, Damiannah Muketthe Kieti. 2003. Measuring Tourist Satisfaction with Kenya's wildlife safari: a case study of Tsavo West Nasional Park. Tourism Managemen 24. 73-81. www.elsevier.com/locate/tourman.

Kotler, P. 2005. Manajemen pemasaran. jilid 1(11th ed)(Benyamin Molan, Penerjemah). Jakarta; PT. Indeks.

Kotler, P dan G, Amstrong. 2008. Prinsipprinsip pemasaran. edisi 12 jilid 1 Jakarta. Erlangga

Maria E. A. G., R.C. Lorenzo, dan F.B. Jose Antonio. 2007. Assessing Tourist Behavioural Intentions Through Perceived Service Quality and Customer Satisfaction, Journal Of Bussiness Research 60, 153160.www.sciencedirect.com

Mowen, C. dan J. M. Minor. 2002. Pelaku konsumen. Jakarta: Erlangga.

Parasuraman. 1985. A Conseptual Model of Service Quality, Journal of Marketing, vol:49, fall 1985,p 47.

Parasuraman. 1988. SERVQUAL: A Multiple Item Scale for Meansuring Consumer Perseption of Service Quality, hal 64, Journal of retailing.

Supranto. 2006. Pengukuran tingkat kepuasan pelanggan untuk menaikkan pangsa pasar: Jakarta. Rineka cipta. 
Suryawardani, I G. A. O. 2018. Evaluation of Marketing Strategy of Sanur Village Festival Bsed on Visitor Behaviour. International Journal of applied Business and Economic research.vol.16, Number 2, 2018.P261-276.ISSN:0972-7302.

Suryawardani, I. G. A. O., A. S. Wiranatha, I. K .G. Bendesa, M. Antara and Mariam Gravari_Basbas. 2017. A Struktural Model of Foreign Tourist Loyalty in Economic Research. V.15 No.19, P.195-211.ISSN:0972-7302.

Yoga, I. P. B. S. A. , I G.A.O. Suryawardani and I. G. A. A. L. Anggreni. 2016. Hubungan Kepuasan dan Kepercayaan terhadap Loyalitas Konsumen Kopi Bubuk Cap Mutiara pendekatan Structural Equation Modeling. Vol. 5. No. 2, ISSN: 2301-6523.

Tjiptono, F. 2004. Manajemen Jasa. edisi pertama. Yogyakarta. Andi Offset.

Tjiptono, F. 2005. Manajemen Jasa. Edisi4.Yogyakarta: Andi

Tjiptono, F. 2006. Ilmu Pariwisata. Jakarta: PT.Pradaya Pramita

Tjiptono, F. 2008. Strategi Pemasaran. Jakarta: PT.Pradaya Pramita

Tricilia D.M.A. 2005. Pengaruh kualitas pelayanan terhadap kepuasan pengunjung Agrowisata. PT.Godongijo asri.

Wiranatha et. Al. 2015. Analisis Kepuasan Konsumen terhadap Kualitas Pelayanan dan Jasa dengan menggunakan metode Infortance Performance Analysis (studi kasus di restoran warung subak, Peguyangan Denpasar).vol.3.No.3. September 2015 P. 51-60. ISSN: 2503-488X.
Yuda Eka Nugraha. 2018. Pengaruh Kualitas Layanan wisata Medis terhadap kepuasan dan loyalitas wisatawan mancanegara pada Klinik Radiance, Kuta, Bali. Jumpa. Universitas Udayana.

Zeithaml Dan Bitner. 2003. Service Marketing Integrating customer focus cross firm,3th. Boston. Mc Growhill/irwin

Zeithaml . 2006. Servises Marketing.Edisi 4. Boston. Prentice Hall; exclusive right by Mc Graw-Hill. 